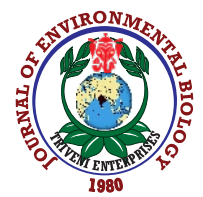

\title{
Dynamics of chitosan based NPK-nanofertilizers in greenhouse cucumber production system
}

\author{
S. Modi', S. Kumar ${ }^{1 *}$ and P.K. Dubey ${ }^{2}$ \\ 'Department of Vegetable Science, ASPEE College of Horticulture and Forestry, Navsari Agricultural University, Navsari-396 450, India \\ ${ }^{2}$ Department of Agricultural Chemistry and Soil Science, Navsari Agricultural University, Navsari-396 450, India
}

*Corresponding Author Email : drsksony@nau.in

\section{Abstract}

Aim: To study the effect of NPK-nonofertilizers on growth, reproductive and yield parameters as well as nutrient recovery efficiency in greenhouse cucumber.

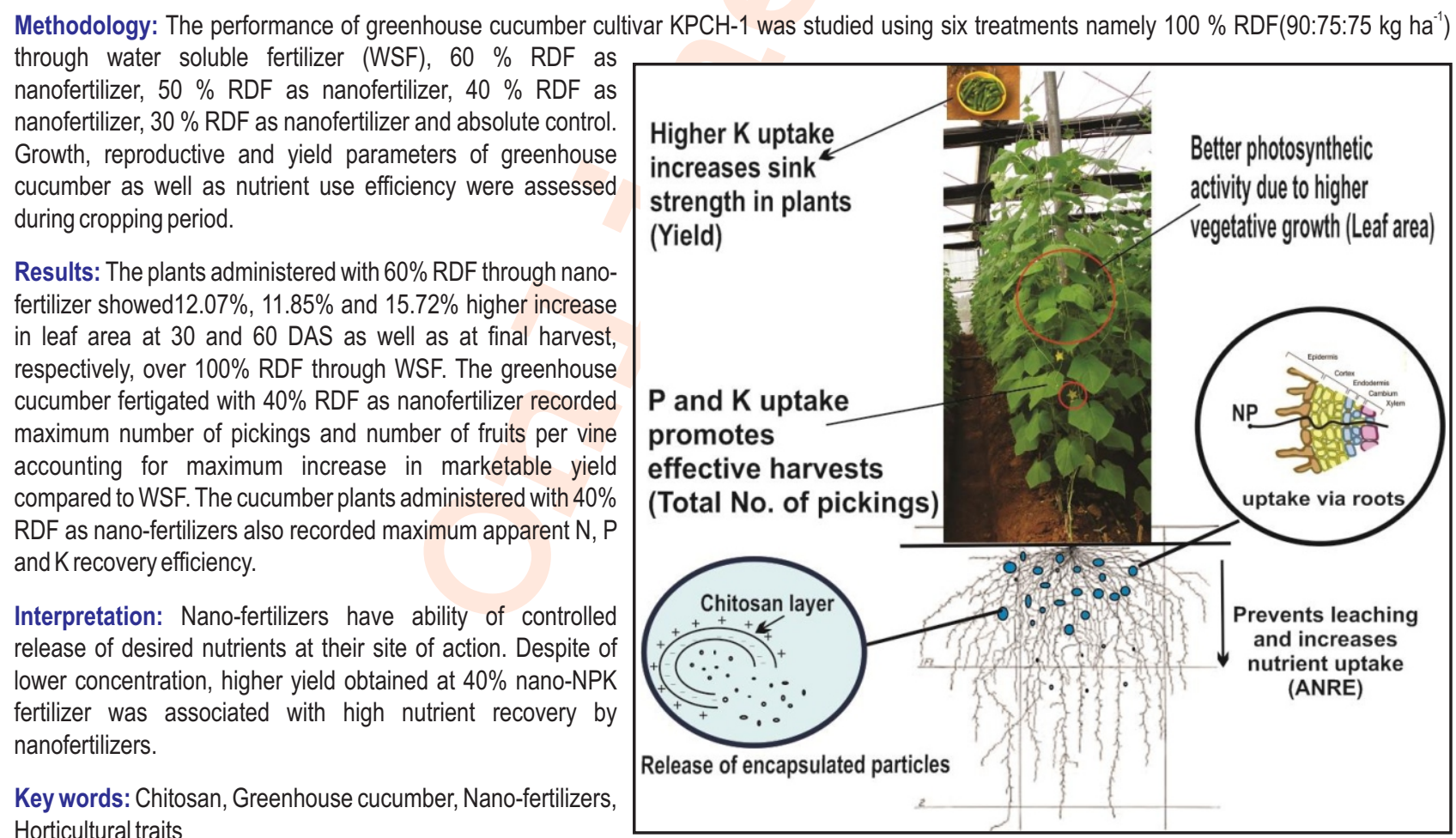

Key words: Chitosan, Greenhouse cucumber, Nano-fertilizers Horticultural traits

How to cite : Modi, S., S. Kumarand P.K. Dubey: Dynamics of chitosan based NPK-nanofertilizers in greenhouse cucumber production system. J. Environ. Biol., 42, 162-168 (2021). 


\section{Introduction}

Cucumber (Cucumis sativus L.) is one of the potential greenhouse vegetable crops, and the availability parthenocarpic cultivars have actually revolutionized greenhouse cucumber production in India. Parthenocarpy is a much desired trait in cucumber production as it minimizes yield irregularity, enhances total yield and makes the production possible under suboptimal environmental conditions (Dhatt and Kaur, 2016). Protected agriculture is the most effective means of overcoming climate diversity, increasing yields, and at the same time significantly improving product quality as desired by market demand (Patidar et al., 2017). Nutrients fulfill crucial requirement of a crop to achieve better plant growth and higher yield, which is primarily met via various agrochemicals. Greenhouse cucumber plants have rapid vegetative and reproductive growth rates, high water and nutrient uptake rates and large root masses, so an adequate supply of nutrients according to the demand of crop is essential to obtain higher yields and quality (Hanjagi and Singh, 2017). The supply of nutrients must be carried out with higher efficiency (Fan et al., 2014; Wang et al., 2015) to maximize crop potential and avoid excessive application of chemical fertilizers that can cause environmental issues (Cao et al., 2015). It has been worked out that NPK chemical fertilizers are currently being used @ 10:2.7:1 in India instead of an optimal ratio of 4:2:1 for better productivity (Qureshi et al., 2018). It has been estimated that more than 90 percent of applied agrochemicals are lost as run-off or in the atmosphere during application, which severely affects sustainability of agriculture and increases application cost (Campos et al., 2015). This has led to loss of major nutrients like nitrogen $(40-70 \%)$, phosphorous (80-90\%) and potassium (50$70 \%$ ) in the environment and consequently lead to imbalance of elements present in the soil, decrease in crop production and lower quality of food (Ditta and Arshad, 2015; Corradini et al., 2010).

The rapid progress in nanotechnology research has sought considerable attention in agricultural and food science through converging science and engineering. In agriculture, nano-materials have potential applications for solving problems by controlled release of encapsulated fertilizers, micronutrients, pesticides and detection of plant diseases, pollutants, pests and pathogens (Ghormade et al., 2011). Controlled release fertilizers have the potential to increase fertilizer use efficiency, which function by keeping nutrients in the form that is less likely to be lost from the root zone and releasing nutrients at a time as close as possible to time of uptake by plant (Reetz, 2016). Nanotechnology-based delivery of biologically active ingredients to target site by carrier like chitosan is one of the key methods in agriculture to address the current challenges caused by adverse environmental conditions and increased demand of food supply (Thornton, 2010). Chitosan is a non-toxic, biodegradable, linear copolymer of 2-acetamido2-deoxy- $\beta$-D-glucopyranose and 2- amino-2-deoxy- $\beta$-D-glucopyranose produced from chitin by deacetylation using alkaline hydrolysis or enzymatic treatment (Choudhary et al., 2017a). Biocompatibility, biodegradability, hydrophilicity, safe, and non-toxic nature of chitosan based nanomaterials make it highly suitable in several agricultural applications like antimicrobial activity (Qi et al. 2004, Saharan et al., 2013, 2015), plant growth promoting activity (Saharan et al., 2015, 2016; Choudhary et al., 2017b) and nanofertilizers (Corradini et al., 2010; Abdel-Aziz et al., 2016). A comprehensive range of molecular weights and degree of acetylation renders chitosan considerably reasonable for the development of nano formulations (Kashyap et al., 2015). Generally, release of bioactive ingredients from chitosan-based nanomaterials occur due to diffusion or degradation release mechanism. The probable mechanisms include swelling of chitosan matrix by penetration of water, conversion of glassy polymer into swollen matrix and a slow and steady release/ diffusion of compounds from the swollen matrix (Kashyap et al., 2015).

Controlled release of encapsulated materials is accomplished due to slow release effect of chitosan nanomaterials and bonding of active ingredients with chitosan. Controlled release system have several advantages like use of active ingredients in smaller quantities and reduced loss during leaching, volatilization and run-offs (Campos et al., 2014). Development of effective tools for controlled and slow release system for delivery of fertilizers at optimum rate to plants has potential to provide significant cost to the farmers as much of the fertilizer applied to crops. Biodegradable chitosan nanomaterials are favourable for use in controlled release of NPK fertilizer due to their bio-absorbable nature (Prasad et al., 2017).

Nanoparticles used as nano-fertilizers are efficiently absorbed by the plant roots due to small size and then transported through apoplastic and symplastic pathways to the xylem, via endodermis and vascular bundles to different parts of the plant. This mode of transport inside plant has been observed for mesoporous silica nanoparticles and SiO nanoparticles (Le et al., 2014). It has been reported that different classes of nanoparticles are transported to cells through endocytosis or through pores or channels (Gao et al., 2008). Presence of essential plant nutrient element in the substrate or soil in the form of nano fertilizer allows better dissolution, faster absorption and assimilation by the plants as compared to traditional fertilizers (Ditta and Arshad, 2016). Therefore, looking to the above perspectives, the present investigation was planned to study the effect of chitosan based NPK nano-fertilizers on various horticultural traits of greenhouse cucumber and to work out apparent nutrient recovery efficiency of chitosan based NPK nano-fertilizers.

\section{Materials and Methods}

Experimental site and materials: The experiment was conducted during kharif, 2018 in multispan saw tooth type 
naturally ventilated polyhouse (NVPH) of $2000 \mathrm{~m}^{2}$ at Regional Horticultural Research Station, ASPEE College of Horticulture and Forestry, Navsari Agricultural University, Navsari, India. The meteorological data inside NVPH was measured periodically throughout the investigation period using thermohygrometer (Model 06-662-4). The mean temperature inside NVPH was $26.7^{\circ} \mathrm{C}$ during cropping period, while the maximum and minimum temperature was $33.5^{\circ} \mathrm{C}$ and $19.7^{\circ} \mathrm{C}$ with average relative humidity of $73.4 \%$. The growing media in the polyhouse proportionally composed of $70 \%$ red soil: $30 \% \mathrm{FYM}$, which was subjected to sterilization with Metam Sodium prior to planting. The initial characteristic property of growing media was as follows: EC $0.9 \mathrm{dS} \mathrm{m}^{-1}, \mathrm{pH} 6.4$, Organic carbon $0.5 \%$, Nitrogen $375.5 \mathrm{~kg} \mathrm{ha}^{-1}$, Phosphorous $45.9 \mathrm{~kg} \mathrm{ha}^{-1}$ and Potassium $291.0 \mathrm{~kg} \mathrm{ha}^{-1}$. These parameters were analysed by the standard protocol (Jackson, 1979).

Chitosan based nanofertilizers were prepared and supplied by the Department of Biotechnology and Biochemistry, College of Agriculture, Junagadh Agricultural University, Junagadh, Gujarat having 2.5\% concentration for each element (N, P and K) and sources of NPK nutrients were urea, single super phosphate and muriate of potash. The experiment was planned with six treatments viz., 100\% RDF (90:75:75 NPK kg ha $\left.{ }^{-1}\right)$ through Water Soluble Fertilizer (WSF); 60\% RDF as nanofertilizer; $50 \%$ RDF as nanofertilizer; $40 \%$ RDF as nanofertilizer; $30 \%$ RDF as nanofertilizer and absolute control in Randomized Block Design (RBD) with four replications on greenhouse cucumber cultivar KAU Parthenocarpic Cucumber Hybrid-1 $(\mathrm{KPCH}-1)$. The seeds treated with imidacloprid 75 FS were sown on raised beds on $28^{\text {th }}$ August, 2018 with inter- and intra-row spacing of $60 \mathrm{~cm}$ and $45 \mathrm{~cm}$, respectively. Each treatment was assigned a gross plot of $3.0 \times 8.1 \mathrm{~m}^{2}$ accommodating 72 plants and net plot of $1.5 \times 7.2 \mathrm{~m}^{2}$ with 32 plants (i.e., 3 plants $\mathrm{m}^{-2}$ ). At the time of sowing, common application of $5 \mathrm{~kg}$ Trichoderma viride, 5 litre Pseudomonas fluorescens, 4 ton vermicompost and $50 \mathrm{~kg}$ micro-nutrients (Grade-5) per ha was done. Cucumber plants were trimmed to a single stem system by cutting side shoots throughout the growing period of crop and administered with fertilizers as per treatments following the fertigation schedule (Kumar et al., 2018).

Growth parameter: To measure the leaf area, three leaves from upper, middle and lower portion of 5 randomly tagged vines from net plot were selected. The maximum length and width of these leaves were measured at 30,60 days after sowing (DAS) as well as at final harvest and average values were substituted into the equation given by Blanco and Foleghatti (2003) having 95\% precision $\left(0.95 R^{2}\right)$.

Reproductive parameter: Total number of pickings was counted starting from first picking to the last picking and summed up to calculate total number of pickings.
Yield parameters: The length and diameter of 5 random fruits from bulk harvests of 5 tagged vines were measured from the pedicel to blossom end of the fruit and diameter at the middle of the fruit was recorded with the help of a digital Vernier caliper (Mitutoyo, Digimatic Caliper).

Total number of fruits harvested from 5 randomly tagged vines during cropping season was counted and weighed at each picking to work out number of fruits per vine and average fruit weight. Total weight of palatable fruits harvested from 5 randomly tagged vines was recorded separately and the average marketable yield per plant was worked out. The fruits harvested from each net plot were weighed separately at each picking to determine marketable yield per plot which was further used to calculate yield per square meter.

Apparent nutrient recovery efficiency: Apparent nutrient recovery efficiency (ANRE) was calculated by the formula given by Aulakh et al. (2000).

Statistical Analyses: The data was analysed using standard procedure of statistical analysis of variance appropriate to the Randomized Block Design (RBD) as described by Panse and Sukhatme (1985). Critical difference (CD) at $5 \%$ level of probability was worked out to compare the treatment means.

\section{Results and Discussion}

The basic plant metabolic processes such as photosynthesis are chiefly associated with leaf area. Plants supplied with $60 \%$ RDF as nano-fertilizer recorded maximum leaf area of $416.4 \mathrm{~cm}^{2}$ and $479.3 \mathrm{~cm}^{2}$ at 30 DAS and final harvest, respectively, followed by $40 \%$ RDF through nano-fertilizer. Similarly, maximum leaf area at 60 DAS $\left(449.0 \mathrm{~cm}^{2}\right)$ was displayed by $60 \%$ RDF as nano-fertilizer, which was statistically at par with that of cucumber plants fertigated with 40 and $50 \%$ RDF through nano-fertilizer. Apparently, the plants administered with $60 \%$ RDF as nano-fertilizer reported highest increase in leaf area of $12.1 \%, 11.9 \%$ and $15.7 \%$ as compared to plants fertigated with 100\% RDF through WSF (Table 1).

An increasing trend in leaf area index of cotton with the increase of nano-NPK fertilizer application rates was also observed by Eleyan et al. (2018). The better uptake of nitrogen in greenhouse cucumber supplied through nanofertilizers might have had synergistic effect of nitrogen and chitosan nanoparticles on leaf expansion and leaf persistency and ultimately on leaf area. Chitosan can efficiently enhance photosynthesis, promotes plant growth and increase nutrient uptake (Chaudhary et al., 2016). Similarly, Alidoust and Isoda (2013) recorded maximum leaf area in soybean upon foliar application of $1000 \mathrm{mg} \mathrm{I}^{-1}$ iron oxide nanoparticles. The appropriate use of nanofertilizers has also contributed towards more leaf area in spinach with better leaf texture (Hossein-Pour et al., 1998). These results can be 
Table 1 : Effect of NPK-nanofertilizers on leaf area of greenhouse cucumber

\begin{tabular}{llll}
\hline Treatment & \multicolumn{3}{c}{ Leaf area $\left(\mathbf{c m}^{2}\right)$} \\
\cline { 2 - 4 } & 30 DAS & 60 DAS & At final harvest \\
\hline 100\% RDF (Through WSF) & 371.5 & 401.4 & 414.2 \\
60\% RDF as Nano-fertilizer & 416.4 & 449.0 & 479.3 \\
50\% RDF as Nano-fertilizer & 368.8 & 415.3 & 431.6 \\
40\% RDF as Nano-fertilizer & 406.7 & 448.8 & 472.7 \\
30\% RDF as Nano-fertilizer & 363.6 & 375.3 & 381.9 \\
00:00:00 NPK kg ha ${ }^{-1}$ (Absolute control) & 356.7 & 366.7 & 379.7 \\
C.D. 0.05 & 40.0 & 43.4 & 40.2 \\
\hline
\end{tabular}

attributed to the positive charge of chitosan nano-particles and potassium content, which may increase osmotic pressure of stomatal cells leading to improved in opening of stomatal cells and stomatal conductance (Ha et al., 2019). As a result of application of nano-fertilizers in the present study, there could be enhancement in photosynthesis net rate of cucumber by entrapping more $\mathrm{CO}_{2}$.

Earliness to marketable maturity in cucumber provides sufficient length of period to get more and effective number of harvests under appropriate level of nutrition. Greenhouse cucumber supplied with 40\% RDF through nano-fertilizer recorded highest number of pickings (27.5) during study period, followed by $50 \%$ RDF as nano-fertilizer (26.0) for the trait. The lowest number of pickings was obtained in absolute control recording only 19.5 pickings during the cropping span of cucumber (Table 2). Prolonged availability of marketable fruits is a desirable attribute of parthenocarpic cucumber. It is well recognized that plant growth and development are largely controlled by phytohormones. Plant nutrient management can potentially change the rate and efficiency of plant growth regulators. Besides, it has been reported that plants fertilized with nitrogen at optimum rate had significantly highest level of auxins and gibberellins (Liu et al., 2011). Higher auxin concentration leads to physiologically more active plants resulting in earliness, greater number of flowers and maximum fruit set (Janmohammadi et al., 2017). As earliness provides enough window for the crop to achieve higher number of pickings, such an observation was also authenticated by the results obtained in chickpea by Drostkar et al. (2016).

The consequent responses of various treatments in context to fruit length, diameter and average weight of greenhouse cucumber showed non-significant variations among different treatments (Table 2). Greenhouse cucumber produced maximum number of fruits per vine (32.2) administered with $50 \%$ RDF as nano-fertilizer. As compared to water soluble fertilizer, plants fertigated with 50\% RDF as nano-fertilizers showed $7.1 \%$ increase in the number of fruits per vine (Table 2). The average fruit weight $(133.9 \mathrm{~g}$ ) was found maximum in $40 \%$ RDF as nanofertilizer treatment. Nano-NPK is considered as biological pump for plants to absorb nutrients and water efficiently (Ma, 2009). The activity of water increase after adding nanomaterials which correspondingly enhances the absorption of nutrients supplied with water and essentially higher production could be achieved (Liu and Liao, 2008). Moreover, chitosan nanoparticles, as a cationic polymer, may interact with negatively charged molecules and polymers showing favourable interaction (Corradini et al., 2010).

Greenhouse cucumber achieved maximum marketable yield per plant through $40 \%$ RDF as nano-fertilizer, which showed $11.4 \%$ gain in yield over $100 \%$ RDF through WSF. The higher number of pickings and number of fruits per vine have contributed towards maximum gain in marketable yield per plant (Table 3 ). It is well established fact that nano sized particles with higher surface area can be readily absorbed by the plants resulting in higher amount of assimilates for increased growth, yield attributes and finally crop yield (Dehner et al., 2010). Mahmaud et al. (2017) reported that interaction of nanoparticles with plants causes many morphological and physiological changes depending on their properties and chemical composition, size and surface covering. Ekinci et al. (2014) fined that nanofertilizers even at lower application rate fulfil the entire requirement of crops for maximum yield. Greenhouse cucumber fertigated with $40 \%$ RDF as nano-fertilizer recorded highest marketable yield per $\mathrm{m}^{2}(12.4$ $\mathrm{kg})$, followed by $50 \%$ RDF as nano-fertilizer $(12.1 \mathrm{~kg})$ and $100 \%$ RDF through WSF $(11.1 \mathrm{~kg})$. The increase in yield per $\mathrm{m}^{2}$ up to $11.2 \%$ due to fertigation with $40 \%$ RDF as nano-fertilizers compared to WSF may be qualified to enhance sink strength of plants. Sink strength depends on two factors namely sink size and sink activity. Nanofertilizers may have affected the sink and source interaction through its nutrient transportation capability in terms of penetration and movement of wide range of nutrients through uptake and movements within the plant. The increased number of fruits and pickings, and marketable yield per plant has ultimately contributed to such an increase in marketable yield per $\mathrm{m}^{2}$ during this investigation. The slow release of nitrogen in NPK fertilizers can be explained due to ionic bond between chitosan nano-particles and nitrogen. These results can also be correlated to the positive charge of chitosan nano-particles and potassium which may increase osmosis pressure of stomatal cells leading to 
Table 2 : Effect of NPK-nanofertilizers on reproductive and yield parameters of greenhouse cucumber

\begin{tabular}{llllll}
\hline Treatment & $\begin{array}{l}\text { Total number } \\
\text { of pickings }\end{array}$ & $\begin{array}{l}\text { Fruit length } \\
(\mathbf{c m})\end{array}$ & $\begin{array}{l}\text { Fruit diameter } \\
\text { (cm) }\end{array}$ & $\begin{array}{l}\text { Number of fruits } \\
\text { per vine }\end{array}$ & $\begin{array}{l}\text { Average fruit } \\
\text { weight }(\mathbf{g})\end{array}$ \\
\hline 100\% RDF (Through WSF) & 25.0 & 14.6 & 3.6 & 30.0 & 132.9 \\
60\% RDF as Nano-fertilizer & 22.8 & 14.8 & 3.6 & 27.2 & 132.2 \\
50\% RDF as Nano-fertilizer & 26.0 & 14.3 & 3.6 & 32.2 & 130.4 \\
40\% RDF as Nano-fertilizer & 27.5 & 15.3 & 3.6 & 32.1 & 133.9 \\
30\% RDF as Nano-fertilizer & 23.8 & 15.4 & 3.6 & 26.9 & 130.9 \\
00:00:00 NPK kg ha-1 (Absolute control) & 19.5 & 14.3 & 3.6 & 16.6 & 129.6 \\
C.D.0.05 & 2.0 & NS & NS & 6.1 & NS \\
\hline
\end{tabular}

Table 3 : Effect of NPK-nanofertilizers on yield and apparent nutrient recovery efficiency of greenhouse cucumber

\begin{tabular}{|c|c|c|c|c|c|}
\hline \multirow[t]{2}{*}{ Treatment } & \multicolumn{2}{|c|}{ Marketable yield (kg) } & \multicolumn{3}{|c|}{ Apparent nutrient recovery efficiency (\%) } \\
\hline & per plant & perm ${ }^{2}$ & Nitrogen & Phosphorous & Potassium \\
\hline $100 \%$ RDF (Through WSF) & 3.9 & 11.1 & 31.0 & 19.6 & 32.0 \\
\hline $60 \%$ RDF as Nano-fertilizer & 3.5 & 10.2 & 42.6 & 27.0 & 50.0 \\
\hline $50 \%$ RDF as Nano-fertilizer & 4.2 & 12.1 & 51.4 & 31.5 & 57.0 \\
\hline $40 \%$ RDF as Nano-fertilizer & 4.3 & 12.4 & 72.7 & 52.9 & 85.0 \\
\hline $30 \%$ RDF as Nano-fertilizer & 3.5 & 10.1 & 53.2 & 51.7 & 83.2 \\
\hline 00:00:00 NPK kg ha ${ }^{-1}$ (Absolute control) & 2.1 & 6.13 & - & - & - \\
\hline C.D..$_{0.05}$ & 0.7 & 1.4 & 6.8 & 5.3 & 5.9 \\
\hline
\end{tabular}

improvement in opening of stomatal cells and stomatal conductance. As a result of application of nano-fertilizers in the presents study, there could be enhancement in photosynthesis net rate of cucumber by entrapping more $\mathrm{CO}_{2}$. The slowest release kinetic amongst NPK in nano-fertilizers could be explained by the content of $P$ in the NPK nano-fertilizers which was cross linked with ammonia residues in chitosan chain ( $\mathrm{Ha}$ et al., 2019). It has also been reported that chitosan may directly affect gene expression, metabolism and induce many biological responses in plants, which may directly or indirectly increase the uptake of nutrients in plants (Ghormade et al., 2011). It means nano-fertilizers are slow release fertilizers which increase in fertilizer use efficiency (Ledezma-Delgadillo et al., 2016)

The cucumber plants fertigated with 40\% RDF as nanofertilizer recorded significantly superior apparent nutrient recovery efficiency to the tune of $72.7 \%, 52.9 \%$ and $85.0 \%$ for $\mathrm{N}$, $\mathrm{P}$ and $\mathrm{K}$, respectively (Table 3). However, it was followed by $30 \%$ RDF as nano-fertilizer for phosphorous $(51.7 \%)$ and potassium (83.3\%). Chitosan nano-layers act as barrier against water penetration during fertilizer release making it slow and steady, thus able to adjust the speed of nutrient release, thereby improving efficiency (Ghahremani et al., 2014; Roshanravan et al., 2015). Hagab et al. (2018) reported that increase in phosphorous use efficiency is due to better absorption and utilization of phosphorous in the form of nanofertilizer as $P$ is slowly released during entire growth period. Chitosan-coated NPK were tested and found effective in providing nutrition to plant more precisely compared to sole NPK application (Lan et al., 2008, Corradini et al., 2010). Moreover, higher solubility of nitrogen, phosphorous and potassium with slow release of nutrients provides steady and constant supply of nutrients to the plant for longer period, thereby increasing utilization by plants. There exist a strong interaction between positively charged amino groups of chitosan and negatively charged cross linking agents like ammonia and phosphate. Amino groups of chitosan also form complex with other charged polymers such as poly acrylic acid, carboxymethyl cellulose, xanthum, carrageenan, alginate and pectin (Kashyap et al., 2015). The main advantage of encapsulating fertilizers in chitosan matrix is protecting active ingredients from the surrounding environment. Controlled release of fertilizers is accomplished due to slow release effect of chitosan nano-materials and bonding of active ingredients with chitosan. Controlled release system offers an advantage of using active ingredients in smaller quantities effectively and reducing loss due to leaching, volatilization and sun-offs, thereby increasing nutrient use efficiency (Campos et al., 2014). The rate of dissolution of fertilizers is reduced by stability of nano-coating, which permits slow and sustained release of coated fertilizers that are more effectively absorbed by plant roots (Duhan et al., 2017)

On the basis of present investigation, it can be concluded that chitosan based NPK nano-fertilizers with their slow release ability of encapsulated nutrients contributed effectively and efficiently towards significantly higher gain in leaf area and yield related traits of greenhouse cucumber even at low application 
rates. Simultaneously, these nano-fertilizers exhibited higher nutrient recovery efficiency over commonly used water soluble fertilizers in greenhouse cucumber production system. Thus, NPK nano-fertilizers can serve as a novel technique for developing sustainable horticulture in near future due to their low and effective requirement, and high nutrient use efficiency with higher ecological services.

\section{Acknowledgment}

The technical and financial support provided by Navsari Agricultural University is highly acknowledged.

\section{Add-on Information}

Authors' contribution: S. Modi: Execution of the experiment, data recording, manuscript writing; S. Kumar: Guiding research of studying, contributed in planing of the experiment statistical analysis, interpretation of data, manuscript writing/editing; P.K. Dubey: member of advisory committee of student, rendered technical session for soil and plant analysis and interpretation, editing of manuscript.

Research content: The research contents is original and has not been published elsewhere

Ethical approval: NotApplicable.

Conflict of interest: The author declares that there is no conflict of interest.

\section{Data from other sources: NotApplicable}

Consent to publish: All authors agree to publish the paper in Journal of Environmental Biology.

\section{References}

Abdel-Aziz, H.M.M., M.N.A. Hasaneen and A.M. Omer: Nano chitosanNPK fertilizer enhances the growth and productivity of wheat plants grown in sandy soil. Span. J. Agric. Res., 14, e0902 (2016).

Alidoust, D. and A. Isoda: Effect of $\mathrm{yFe}_{2} \mathrm{O}_{3}$ nanoparticles on photosynthetic characteristic of soybean (Glycine max (L.) Merr.): Foliar spray versus soil amendment. Acta Physiol. PI., 35, 33653375 (2013).

Aulakh, M.S., T.S. Khera, J.W. Doran, K. Singh and B. Singh: Yields and nitrogen dynamics in a rice-wheat system using green manure and inorganic fertilizer. Soil Sci. Soc. American J., 64, 1867-1876 (2000).

Blanco, F.F. and M.V. Folegatti: Anew method for estimating the leaf area index of cucumber and tomato plants. Horticult. Brasil., 21, 666669 (2003).

Campos, E.V.R., J.L. de Oliveira and L.F. Fraceto: Applications of controlled release systems for fungicides, herbicides, acaricides, nutrients, and plant growth hormones: A review. Adv. Sci. Eng. Med. 6, 373-387 (2014).

Campos, E.V.R., J.L. Oliveira, L.F. Fraceto and B. Singh: Polysaccharides as safer release systems for agrochemicals. Agron. Sustain. Dev., 35, 47-66 (2015)

Cao, J., J. Lee, J. Six, Y. Yan, F. Zhang and M. Fan: Changes in potential denitriûcation-derived NO emissions following conversion of grain to greenhouse vegetable cropping systems. Eur. J. Soil Biol., 68, 94-100 (2015).

Chaudhary, M.K., R.V. KumaraSwamy and V. Saharan: Novel prospective for chitosan based nano-materials in precision agriculture-Areview. The Bioscan, 11, 2287-2291 (2016).

Choudhary, R.C., R.V. Kumaraswamy, S. Kumari, S.S. Sharma, A. Pal, R. Raliya, P. Biswas and V. Saharan: Cu-chitosan nanoparticle boosts defense responses and plant growth in maize (Zea mays L.). Sci. Rep., 7, 9754 (2017a).

Choudhary, R.C., R.V. Kumaraswamy, S. Kumari, S.S. Sharma, A. Pal, R. Raliya, P. Biswas and V. Saharan: Synthesis, characterization, and application of chitosan nanomaterials loaded with zinc and copper for plant growth and protection. In: Nanotechnology (Eds.: R. Prasad, M. Kumar and V. Kumar). Springer Nature, pp. 227-247 (2017b).

Corradini, E., M.R. de Moura and L.H.C. Mattoso: A preliminary study of the incorporation of NPK fertilizer into chitosan nanoparticles. Express Polym. Lett., 4, 509-515 (2010).

Dehner, C.A., L. Barton, P.A. Maurice and J.L. Dubois: Size dependent bioavailability of hematite $\left(\mathrm{a}-\mathrm{Fe}_{2} \mathrm{O}_{3}\right)$ nanoparticles to a common aerobic bacterium. Env. Sci. Technol., 45, 977-983 (2010).

Dhatt, A.S. and G. Kaur: Parthenocarpy: A potential trait to exploit in vegetable crops: Areview. Agril Rev., 37, 300-308 (2016).

Ditta, A. and M. Arshad: Applications and perspectives of using nanomaterials for sustainable plant nutrition. Nanotech. Rev., 2, 209-229 (2016).

Drostkar, E., R. Talebi and H. Kanouni: Foliar application of Fe, Zn and NPK nano-fertilizers on seed yield and morphological traits in chickpea under rainfed condition. J. Res. Eco., 4, 221-228 (2016).

Duhan, J.S., R. Kumar, N. Kumar, P. Kaur, K. Nehra and S. Duhan: Nanotechnology: The new perspective in precision agriculture. Biotechnol. Rep., 15, 11-23 (2017).

Ekinci, M., A. Dursun, E. Yildirim and F. Parlakova: Effects of nanotechnology liquid fertilizers on the plant growth and yield of cucumber (Cucumis sativus L.). Acta Sci. Pol. Hortorum. Cultus, 13, 135-141 (2014).

Eleyan, S.E.D., A.A. Abodahab, A.M. Abdallah and H.A. Rabeh: Effect of nitrogen, phosphorous and potassium nanofertilizers with different application times, methods and rates on some growth parameters of Egyptian cotton (Gossypium barbadense L.). Biosci. Res., 15, 549-564 (2018).

Fan, Z., S. Lin, X. Zhang, Z. Jiang, K. Yang, D. Jian, Y. Chen, J. Li, Q. Chen and J. Wang: Conventional ûooding irrigation causes an overuse of nitrogen fertilizer and low nitrogen use efûciency in intensively used solar greenhouse vegetable production. Agric. WaterManag., 144, 11-19 (2014).

Gao, F., C. Liu, C. Qu, L. Zheng, F. Yang, M. Su and F. Hong: Was improvement of spinach growth by nano- $\mathrm{TiO}_{2}$ treatment related to the changes of Rubisco activase? Biometals, 21, 211-217 (2008).

Ghahremani, A., K. Akbari, M. Yousefpour and H. Ardalani: Effects of nano-potassium and nano-calcium chelated fertilizers on qualitative and quantitative characteristics of Ocimum basilicum. Int. J. Pharm. Res. Sch., 3, 235-241 (2014).

Ghormade, V., M.V. Deshpande and K.M. Paknikar: Perspectives for nano-biotechnology enabled protection and nutrition of plants. 
Biotechnol. Adv., 29, 792-803 (2011).

Ha, N.M.C., T.H. Nguyen, S.L. Wang and A.D. Nguyen: Preparation of NPK nano-fertilizers based on chitosan nanoparticles and its effect on biophysical characteristics and growth of coffee in greenhouse. Res. Chem. Intermed., 45, 51-63 (2019).

Hagab, R.H., Y.H. Kotp and D. Eissa: Using nanotechnology for enhancing phosphorous fertilizer use efficiency of peanut bean grown on sandy soil. J. Adv. Phar. Edu. Res., 8, 59-67 (2018).

Hanjagi, P.S. and B. Singh: Interactive regulation of iron and zinc nutrition in wheat (Triticum aestivum L.). Indian J. Plant Physiol., 22, 70-78 (2017).

Hossein-Pour, M., D. Hashemi, Ghalavand and H.M. Sharifi: Effect of nitrogen fertilizer and plant density on growth and some measure of dezful in the area of sugar beet. In: Fifth Congress of Plant Agriculture reform in Iran. Dissemination of Agricultural Education, p. 317 (1998)

Jackson, M.L.: Soil Chemical Analysis, $2^{\text {nd }}$ Edn., Prentice Hall of India Pvt., New Delhi, p. 895 (1979).

Janmohammadi, M., N. Sabaghnia, A. Seifi and M. Pasandi: The impacts of nano-structured nutrients on chickpea performance under supplemental irrigation. Acta Univ. Agric. etSilvic. Mendel. Brun., 65, 859-870 (2017).

Kashyap, P.L., X. Xiang and P. Heiden: Chitosan nanoparticle-based delivery systems for sustainable agriculture. Int. J. Biol. Macromol., 77, 36-51 (2015).

Kumar, S., N.B. Patel and S.N. Saravaiya: Influence of fertigation and training systems on yield and other horticultural traits in greenhouse cucumber. Indian J. Hort., 75, 252-258 (2018).

Lan, Wu, L. and M. Liu: Preparation and properties of chitosan coated NPK compound fertilizer with controlled-release and water retention. Carbohydr. Polym., 72, 240-247 (2008).

Le, V.N., Y. Rui, X. Gui, X. Li, S. Liu and Y. Han: Uptake, transport, distribution and bio-effects of $\mathrm{SiO}_{2}$ nanoparticles in Bt-transgenic cotton. J. Nanobiotechnol., 12, 50 (2014).

Ledezma-Delgadillo, A., R. Carrillo-Gonzalez, E.S. Martin-Martinez, M.R. Jaime-Fonseca and M.A. Chacon-Lopez: Nanocapsules of urea in chitosan and polymethacrylic acid and their application to hydroponic culture of lettuce. Rev. Mex. Ing. Quim., 15, 423-431 (2016).

Liu, A.X. and Z.W. Liao: Effects of nano-materials on water clusters. J. Anhui. Agri. Sci., 36, 15780-15781 (2008).

Liu, Y., Y. Ding, Q. Wang, D. Meng and S. Wang: Effects of nitrogen and 6 benzylaminopurine on rice tiller bud growth and changes in endogenous hormones and nitrogen. Crop Sci., 51, 786-792 (2011).

Ma, J., J. Liu and Z.M. Zhang: Application study of carbon nano-fertilizer on growth of winter wheat. Humic Acid, 2, 14-20 (2009).
Mahmoud, A.W.M., A.B. El-Attar and A.A. Mahmoud: Economic evaluation of nano and organic fertilizers as an alternative source to chemical fertilizers on Carum carvi L. plant yield and components. Agriculture (Pol'nohospodárstvo), 63, 33-49 (2017).

Panse, V.G. and P.V.C. Sukhatme: Statistical Methods For Agricultural Workers. Indian Council of Agricultural Research, New Delhi, India, pp. 152-161 (1985).

Patidar, D.K., I.B. Maurya and P. Singh: Effect of micronutrients on yield and economics of gynoecious cucumber (Cucumis sativus L.) var. Kian under naturally ventilated polyhouse. Int. J. Farm Sci., 7, 29$32(2017)$.

Prasad, R., A. Bhattacharyya and Q.D. Naguyen: Nanotechnology in sustainable agriculture: Recent developments, challenges, and perspectives. Front. Microbiol., 8, 10-14 (2017).

Qi, L., Z. Xu, X. Jiang, C. Hu and X. Zou: Preparation and antibacterial activity of chitosan nanoparticles. Carbohydr. Res., 339, 2693-2700 (2004).

Qureshi, A., D.K. Singh and S. Dwivedi: Nano-fertilizers: A novel way of enhancing nutrient use efficiency and crop productivity. Int. J. Curr. Microbiol. App. Sci., 7, 3325-3335 (2018).

Reetz, H.F.Jr.: Fertilizers and their efficient use. Industrial Fertilizer Industry Association, Paris, France, p. 42 (2016).

Roshanravan, B., S.M. Soltani, S.A. Rashid, F. Mahadavi and M.K. Yusop: Enhancement of nitrogen release properties of urea kaolinite fertilizer with chitosan binder. Chem. Spec. Bio., 27, 4451 (2015).

Saharan, V., A. Mehrotra, R. Khatik, P. Rawal, S.S. Sharma and A. Pal: Synthesis of chitosan based nanoparticles and their in-vitro evaluation against phytopathogenic fungi. Int. J. Biol. Macromol., 62, 677-683 (2013).

Saharan, V., G. Sharma, M. Yadav, M.K. Choudhary, S.S. Sharma, A. Pal, R. Raliya P. and P. Biswas: Synthesis and in-vitro antifungal efficacy of Cu-chitosan nanoparticles against pathogenic fungi of tomato. Int. J. Biol. Macromol., 75, 346-353 (2015).

Saharan, V., R.V. Kumaraswamy, R.C. Choudhary, S. Kumari, A. Pal, R. Raliya and P. Biswas: Cu-chitosan nanoparticle mediated sustainable approach to enhance seedling growth in maize by mobilizing reserved food. J. Agric. Food Chem., 64, 6148-6155 (2016).

Thornton, P.K.: Livestock production: Recent trends, future prospects. Phil. Trans. R. Soc., B 365, 2853-2867 (2010).

Wang, C., F. Gu, J. Chen, H. Yang, J. Jiang, T. Du and J. Zhang: Assessing the response of yield and comprehensive fruit quality of tomato grown in greenhouse to deûcit irrigation and nitrogen application strategies. Agril. Water Manag., 161, 9-19 (2015) 